\title{
Evaluation of Pochonia chlamydosporia (Goddard) Isolates for Suppression of Meloidogyne incognita, Root-Knot Nematode of Tomato
}

\author{
Muhammad Nazir Uddin ${ }^{1}$, Saifullah'2, Musharaf Ahmad ${ }^{2}$, Wajid Khan ${ }^{1} \&$ Bilal Muhammad Khan ${ }^{3}$ \\ ${ }^{1}$ Center for Biotechnology and Microbiology, University of Swat, Pakistan \\ ${ }^{2}$ Department of Plant Pathology, Khyber Pakhtunkhwa, Agricultural University Peshawar, Pakistan \\ ${ }^{3}$ Guangdong Provincial Key Laboratory of Marine Biotechnology, STU-UNIVPM Joint Algal Research Center, \\ Department of Biology, College of Science, Shantou University, Shantou, Guangdong, China \\ Correspondence: Wajid Khan, Center for Biotechnology and Microbiology, University of Swat, Pakistan. E-mail: \\ sherafghan.shah@gmail.com
}

Received: November 20, 2018

Accepted: January 24, 2019

Online Published: April 15, 2019

doi:10.5539/jas.v11n5p70

URL: https://doi.org/10.5539/jas.v11n5p70

\begin{abstract}
Restricted applications of chemical nematicides has directed to the development of ecofriendly alternatives. Culture filtrates in different concentrations $(20,40,60,80$ and 100\%) of the six isolates of Pochonia chlamydosporia were evaluated for their nematicidal activity. Significant variations were observed in the inhibitory activity of culture filtrates against egg hatching and second stage juveniles of $M$. incognita at different concentrations. The culture extract of PC-6 showed maximum inhibition of egg hatching followed by PC-1. On the other hand PC1 isolate caused high mortality of second stage juveniles followed by PC-6. Significant variation among the isolates was observed for parasitism of $M$. incognita juveniles and eggs. Among the tested isolates, PC-1 and PC-6 were selected for the further studies based on in vitro egg inhibition and larval mortality. Both PC1 and PC6 applied at the rate of $6 \times 10^{3}$ chlamydospores per gram of soil per plant reduced the population of nematode and improved the growth and productivity of plant under screen house and field conditions. Different growth parameters like plant height, fresh shoot weight, dry shoot weight, fresh root weight and dry root weight were measured. Efficacy of isolates was different in winter and summer crop. No significant difference among the treatments was observed in summer crop. However in winter crop, considerable effect of both isolates was observed. Fungal application was effective at the rate of $6 \times 10^{3}$ chlamydospores per gram of soil per plant in both winter and summer crops. Root coating with chlamydospores suspension significantly reduced number of galls on roots. Little effect of both isolates was observed with mycelial root coating. No lesions were seen on $P$. chlamydosporia inoculated roots of tomato plants.
\end{abstract}

Keywords: culture filtrates, pathogen, biocontrol, chlamydospores

\section{Introduction}

Root-knot nematode (Meloidogyne incognita) is a major and endemic pathogen of tomato crop in northern part of Khyber Pakhtunkhwa province of Pakistan (Musarrat, Firoza, \& Shahina, 2006). Average crop losses due to this pathogen in vegetable crops may reach up to 50-80\% (Ornat \& Sorribas, 2008; Sikora \& Fernandez, 2005). Characteristic symptoms of infected plant are knots or galls on roots at the point of infection (Agrios, 2004). These galls disrupt the vascular tissue of roots that interfere with uptake of water and mineral and translocation of photosynthate resulting in stunted growth, chlorosis and wilting of the plant (Palomares-Rius, Escobar, Cabrera, Vovlas, \& Castillo, 2017). Chemical control is a common mean of controlling plant diseases (Hirooka \& Ishii, 2013; Duponnois, Chotte, \& Sall, 2001). However, chemicals penetrate poorly into roots tissue to contact nematode eggs. They also can cause environmental problems (Garima, Singh, \& Trivedi, 2005; Ploeg, 2002; Kerry, 2000). The use of resistant cultivars is a valuable component in Root-knot nematode management but in many important crops their resistant cultivars are not available. Moreover the effectiveness of some resistant cultivar is restricted to a few races of the nematode (Briar, Wichman, \& Reddy, 2016). Meloidogyne incognita has a wide host range, which makes crop rotation impracticable. Thus, for controlling this nematode, long term integrative approches and development of alternatives of chemical pesticide is urgently needed to protect our crops 
from the risk of this pathogen (Martin, 2003). The nematophagous fungus P. chlamydosporia (Goddard) is an egg nematode parasite and has been found as an effective in biological management of cyst and Root-knot nematodes (Kerry \& Bourne, 2002). The fungus survives in the soil as chlamydospores (Manzanilla-Lopez et al., 2013) and develops colonies around nematodes eggs and attached with eggs shells through appressoria (Lopez-Llorca, Macia-Vicente, \& Jansson, 2008). Then the fungus penetrates into egg by physical pressure and enzymatic activities of different enzymes including proteases, lipases, chitinases and collagenases (Tikhonov, Lopez-Llorca, Salinas, \& Jansson, 2002; Kopcke, Wolf, Anke, \& Sterner, 2001). P. chlamydosporia isolates showed variation in their bio control efficiency depending on different factors i.e., fungal growth rate and its initial population in the rhizosphere, chlamydospores and enzymes productions, availability of water and fungal growth supported by the host plant species (Manzanilla-López et al., 2013; Bourne \& Kerry, 2000). Utilization of biological agents in a management of Root-knot nematode in tomato crop is a good alternative of chemical pesticides in places infested with root-knot nematodes. Therefore the present study was designed for the collection of isolates of P.chlamydosporia from different region of Khyber Pakhtunkhawa, Pakistan and to evaluate their efficacy against M. incognita.

\section{Materials and Methods}

\subsection{Survey and Sampling}

Root-knot nematodes field were surveyed for isolation of P. chlamydosporia. About 150 roots and rhizosphere soil were randomly collected from 35 different locations of Khyber Pakhtunkhwa province of Pakistan. Samples were sealed in plastic bags and brought from field to laboratory at the department of Plant Pathology, the Agriculture University and stored in refrigerator at $4{ }^{\circ} \mathrm{C}$ until use.

\subsection{Separation of Root-knot Nematodes From Roots}

Eggs and females of root-knot nematode were separated from the gall roots, collected randomly from field following standard method of Barker et al. (1985). Briefly, pieces of gall root were rinsed with tap water for 3-5 min to remove the soil, cut into small pieces and then blended in an electric blender. Nematode eggs were collected on $26-\mu \mathrm{m}$-aperture sieve while the females on $75 \mu \mathrm{m}$ sieve. The females and eggs were stored in $1 \%$ saline solution in separate beakers (Hussey \& Barker, 1973).

\subsection{Identification and Mass Production of P. chlamydosporia}

Sodim hyphochloride solution ( $\mathrm{NaOCl} 1 \%$ ) was used for surface steralization of females and egg masses for 30 seconds to relaese eggs. After sterilization the eggs were rinsed three times with sterile distilled water. The eggs were then put on semiselective medium developed by Kerry et al. (1993). The composition of media per liter was $17 \mathrm{~g}$ corn meal agar (Oxoid), $37.5 \mathrm{mg}$ carbendazim, $75 \mathrm{mg}$ rose bengal, $37.5 \mathrm{mg}$ thiabendazole, $17.5 \mathrm{mg} \mathrm{NaCl}$ and $3 \mathrm{ml}$ Triton X 100, supplemented with $0.2 \mathrm{~g} / \mathrm{L}$ of streptomycin sulfate and $5 \mathrm{mg} / \mathrm{L}$ of penicillin. The plates were incubated at $25{ }^{\circ} \mathrm{C}$. After three days, $P$. chlamydosporia isolates were identified (Barnett \& Hunter, 1998) and then grown on grains for mass production of $P$. chlamydosporia. Extraction of chlamydospores was done using standard method of (Crump \& Kerry, 1981).

\subsection{Culture Filtrate (CF) of Pochonia chlamydosporia}

Small agar pieces $(4-5 \mathrm{~cm})$ of fresh culture of P. chlamydosporia were put in to $250 \mathrm{ml}$ Erlenmeyer flasks containing sterile potato dextrose broth. The flasks were sealed and incubated at $25{ }^{\circ} \mathrm{C}$ for 10 days on a rotatory shaker. The filtrate was centrifuged at $8,000 \mathrm{rpm}$ for 20 minutes. Mycelial mat, hyphae and spore were removed passing through sterile Whatman filter paper $(0.2 \mu \mathrm{m})$ (Kerry, 1986) and stored at $4{ }^{\circ} \mathrm{C}$.

\subsection{Single Species Nematode Culture}

Single egg mass and identified female of Meloidogyne incognita was collected and inoculated in 3 weeks old nursery seedlings of tomato $\mathrm{cv}$. Money maker (tomato)were raised in earthen pots containing sterilized soil. The egg masses were collected 50 days after inoculation and re-cultured them.

\subsection{Effect of Culture Filtrate on Egg Hatching and $J_{2}$ Mortality}

Effect of culture filtrate of $P$. chlamydosporia isolates on $M$. incognita was determined by using standard method described by (Mukhtar \& Pervaz, 2003). Different concentrations (20, 40, 60, 80 and 100\%) of culture filtrate were pepared. Approximately 100 eggs of $M$. incognita from freshly cultured inoculum were treated with $1 \%$ sodium hypochlorite $(\mathrm{NaOCl})$ solution for 30 seconds and then transferred to into $5 \mathrm{~cm}$ diameter petri plates containing $5 \mathrm{ml}$ of each dilution of culture filtrate. Eggs in sterilized distilled water were used as control. The treatments were replicated six times at intervel of 24,48 and 72 hours. For testing the effect of culture filtrate on $\mathrm{J}_{2}$ mortality, five milli-litre $(5 \mathrm{ml})$ of each dilution of the culture filtrate was poured in $5 \mathrm{~cm}$ diameter petri plates. 
Each petridish was plated with 50 fresh hatched second stage juveniles of $M$. Incognita. Sterilized distilled water having juviniles was used as control. The treatments were replicated six times. Effect of culture filterate was checked at 24, 48 and $72 \mathrm{hrs}$. Under a stereomicroscope the the number of live or dead juveniles were counted by probing nematodes with a fine needle to differentiate paralyzed or dead nematodes from live ones (Ayatollahy, Fatemy, \& Etebarian, 2008).The assay was repeated twice. Percentage of juvenile mortality was noted (Sun, Gao, Shi, Li, \& Liu, 2006).

\subsection{Parasitism of Eggs and $J_{2}$}

Five isolates of $P$. chlamydosporia were tested against $M$. incognita eggs and $\mathrm{J}_{2}$ for their parasitism. The experiment was performed in $5 \mathrm{~cm}$ diameter petri plates filled with $1.5 \%$ water agar. Five hundred micro-litre (500 $\mu 1)$ drop containing 100 eggs and 50 freshly hatched juveniles of $M$. incognita was spread on media plate in laminar flow cabinet. Plates were incubated at $25{ }^{\circ} \mathrm{C}$ for 15 days. Sterile distilled water containing eggs or juviniles were used as control (Freire \& Bridge, 1985; De Leij \& Kerry, 1991). Each treatment was replicated six times. Eggs and juveniles were stained with acid fuchsin $(3.5 \mathrm{gm}$ acid fuchsin in $250 \mathrm{ml}$ of acetic acid and $750 \mathrm{ml}$ of distilled water) and then examined under the microscope. Number of infected and uninfected juviniles and eggs were counted (Kerry \& Crump, 1977).

\subsection{Root Coating With Mycelia of P. chlamydosporia}

Plugs $(4-5 \mathrm{~cm})$ of 10 days old culture were transferred in to erlenmeyer flasks containing potato dextrose broth and then incubated in shaking incubator at $170 \mathrm{rpm}$ for 10 days at $25^{\circ} \mathrm{C}$. Mycelial mat was cut into fragments with a blender and poured in beaker. Roots of tomato seedlings were dipped in the beaker and hand shaken for 5-10 seconds and then planted in pots and field.

\subsection{Root Coating With Chlamydospores of P. chlamydosporia}

Wet roots of tomato seedlings were dipped in the bottles containing chlamydospores developed on millet and hand shaken for 10-20 seconds so that the spores adhere to the roots. The seedlings were transplanted to pots and field.

\subsection{Screen House Study}

Seedlings of tomato germplasm (Money Maker) was grown in earthen pots in screen house. Seedling of three weeks old were planted in plastic pots filled with autoclaved soil $(2.5 \mathrm{~kg})$ with sand, silt and clay contents of 2:1:1. Seven days after trasplantation, 10,000 fresh eggs of M. incognita were applied to rhizosphere of each plant. Small holes around the plants were made and eggs and biocontrol agent was applied according to the treatments. The experiment was performed with fifteen treatment and five replication arranged in randomized complete block design (RCBD) (Table 1).

Table 1. List of treatment applied to tomato germplasm under screen house conditions

\begin{tabular}{ll}
\hline Treatment & Description \\
\hline T0 & Control-1 (no nematodes and no fungus) \\
T1 & Control-2 (only nematodes and no fungus) \\
T2 & only fungus PC-1 \\
T3 & only fungus PC-6 \\
T4 & Two thousand chlamydospores $(\mathrm{PC}-1) / \mathrm{g}$ of soil + nematodes \\
T5 & Four thousand chlamydospores $(\mathrm{PC}-1) / \mathrm{g}$ of soil + nematodes \\
T6 & Six thousand chlamydospores $(\mathrm{PC}-1) / \mathrm{g}$ of soil + nematodes \\
T7 & Two thousand chlamydospores $(\mathrm{PC}-6) / \mathrm{g}$ of soil + nematodes \\
T8 & Four thousand chlamydospores $(\mathrm{PC}-6) / \mathrm{g}$ of soil + nematodes \\
T9 & Six thousand chlamydospores $(\mathrm{PC}-6) / \mathrm{g}$ of soil + nematodes \\
T10 & Substrate alone (no fungus application) \\
T11 & Root coating with $P$. chlamydosporia mycellia $(\mathrm{PC}-1)$ \\
T12 & Root coating with $P$. chlamydosporia mycellia $(\mathrm{PC}-6)$ \\
T13 & Root coating with $P$. chlamydosporia chlamydospores $(\mathrm{PC}-1)$ \\
T14 & Root coating with $P$. chlamydosporia chlamydospores $(\mathrm{PC}-6)$ \\
\hline
\end{tabular}

The experiment was terminated after 60 days of inoculation. Data were noted for shoot length $(\mathrm{cm})$, fresh and dry shoot weight (g), fresh and dry root weight $(\mathrm{g})$, number of galls and number of eggs per plant root system, numbers 
of flowers and fruits per plant, and fruits weight per plant $(\mathrm{kg})$.

\subsection{Field Experiment}

Field study was conducted in a root-knot nematode infested field in the two crop seasons i.e., summer and winter crop. Tomato $c v$. Rio-grande was used in both seasons. Twelve (12) treatments were applied to four week old seedlings in randomized complete block design and 4 replications. Each replication consisted of 10 plants. Cross contamination between treatments was prevented by following the practices suggested by (Verdejo-Lucas, Sorribas, Ornat, \& Galeano, 2003). Treatments applied in field experiment were listed in Table 2.

Table 2. List of treatment applied to tomato germplasm under field conditions

\begin{tabular}{ll}
\hline Treatment & Description \\
\hline To & Control (no fungus) \\
T1 & Two thousand Chlamydospores $(\mathrm{PC}-1) / \mathrm{g}$ of soil \\
T2 & Four thousand Chlamydospores $(\mathrm{PC}-1) / \mathrm{g}$ of soil \\
T3 & Six thousand Chlamydospores $(\mathrm{PC}-1) / \mathrm{g}$ of soil \\
T4 & Two thousand Chlamydospores $(\mathrm{PC}-6) / \mathrm{g}$ of soil \\
T5 & Four thousand Chlamydospores $(\mathrm{PC}-6) / \mathrm{g}$ of soil \\
T6 & Six thousand Chlamydospores $(\mathrm{PC}-6) / \mathrm{g}$ of soil \\
T7 & Substrate alone (no fungus) \\
T8 & Root coating with P.chlamydosporia mycellia (PC-1) \\
T9 & Root coating with P.chlamydosporia mycellia (PC-6) \\
T10 & Root coating with P.chlamydosporia chlamydospores (PC-1) \\
T11 & Root coating with P.chlamydosporia chlamydospores (PC-6) \\
\hline
\end{tabular}

Field experiment was ended at 50 days after transplantation. Data regarding different parameters noted in sreen house trial was also recorded in field trial. Furthere more initial nematode population $(P i)$ and final nematode population $(P f)$ were also measured in field trial.

\subsection{Stastical Analysis}

The data collected from field, green house and experiments were subjected to analysis of variance (ANOVA) using MSTAT-C (Statistical software package). Least significant difference test (LSD) test was applied to the data for the separation of means at $\mathrm{P} \leq 0.05$ (Steel \&Torrie, 1980).

\section{Results}

Under in vitro conditions, culture filtrate of $P$. chlamydosporia was active against the root-knot nematode, $M$. incognita, at different concentrations. Among the tested isolates PC-1 and PC-6 were more effective either in egg hatch inhibition, killing juviniles and infecting eggs of the fungal culture (Figures 1 and 3). Egg hatching inhibition was increased with increasing the concentration of culture filtrate (Figure 2). PC-6 fungal extract showed maximum inhibition of egg hatch (58.17\%) followed by PC-1 extract. Minimum egg hatch inhibition was noted in in PC-4 filtrate with $20 \%$ concentration (Figure 1). 


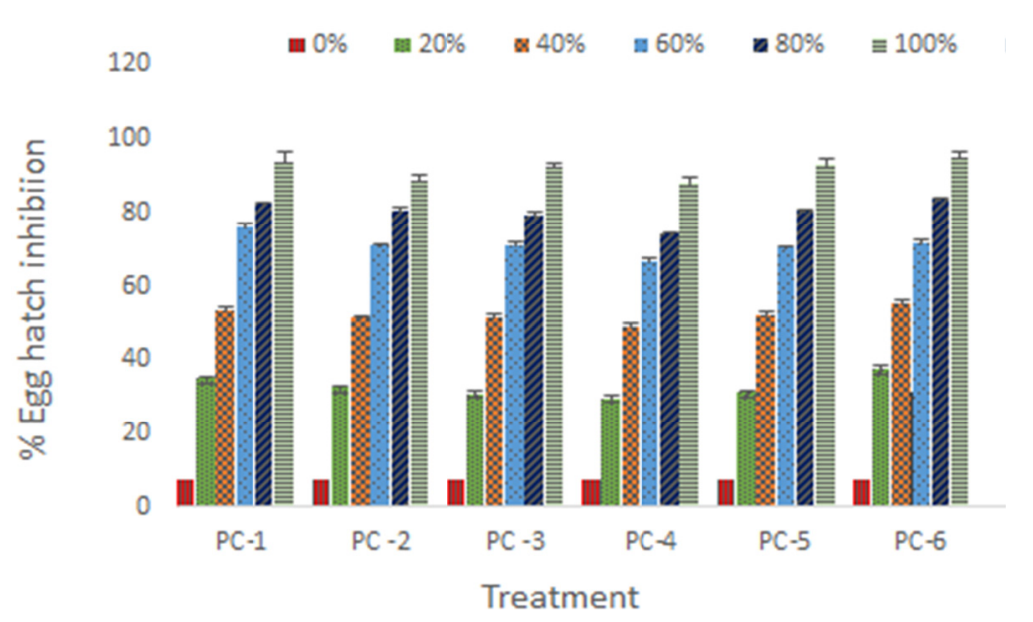

Figure 1. Efficacy of different concentrations of extract of Pochonia chlamydosporia isolates on egg hatching of $M$. incognita after $72 \mathrm{~h}$ at $25 \pm 1^{\circ} \mathrm{C}($ Bar represent mean $\pm \mathrm{SD}$ at $P<0.05)$

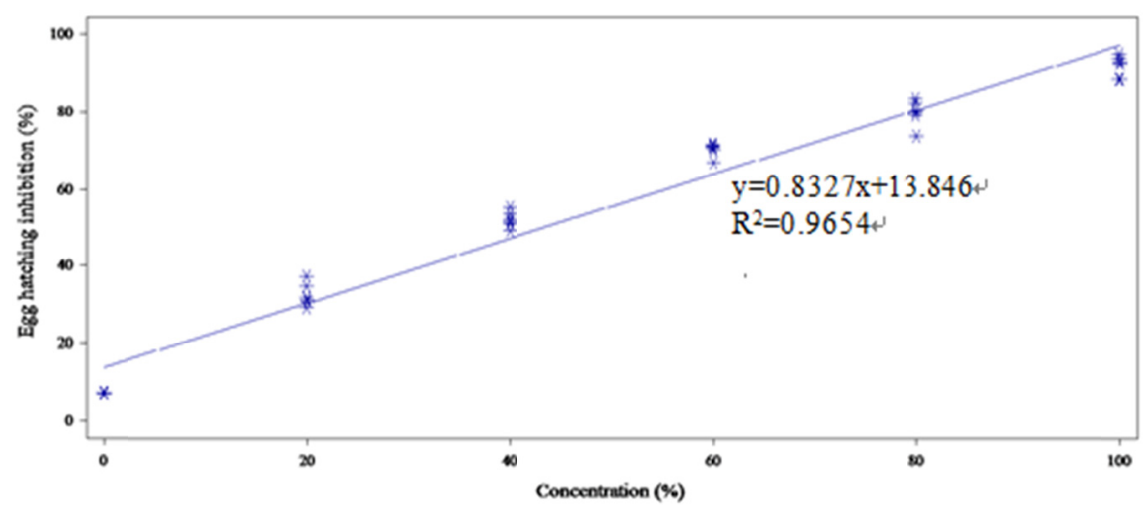

Figure 2. Egg hatching inhibition (\%) of M. incognita against the tested concentrations of the culture filtrate of the isolates of $P$. chlamydosporia $\left(\mathrm{R}^{2}=0.9654\right)$

Potato dextrose broth medium and water did not produced any negative impact on egg hatch inhibition and mortality of juviniles and thus they did not differ significantly from each other. The effect of $P$. chlamydosporia filtrate and their concentrations on mortality of second stage juveniles was significant as compared to control (P $\leq 0.05$ ). Percent mortality of $M$. incognita juveniles was increased with increasing concentration of the culture filtrate (Figure 4). The impact of isolates on mortality of $M$. incognita juveniles was in the range of 11.3-76.3\% after $72 \mathrm{~h}$. Comparison of the tested samples indicated that the culture filtrate of PC-6 killed maximum number of M. incognita J2 (76.3\%) followed by PC-1 (74.0\%) at 100\% concentration. The lowest J2 mortality (11.3\%) was noted in PC-4 filtrate at $20 \%$ concentration. Sterile distilled water (control) caused smallest mortality of J2 $(7 \%)$. 


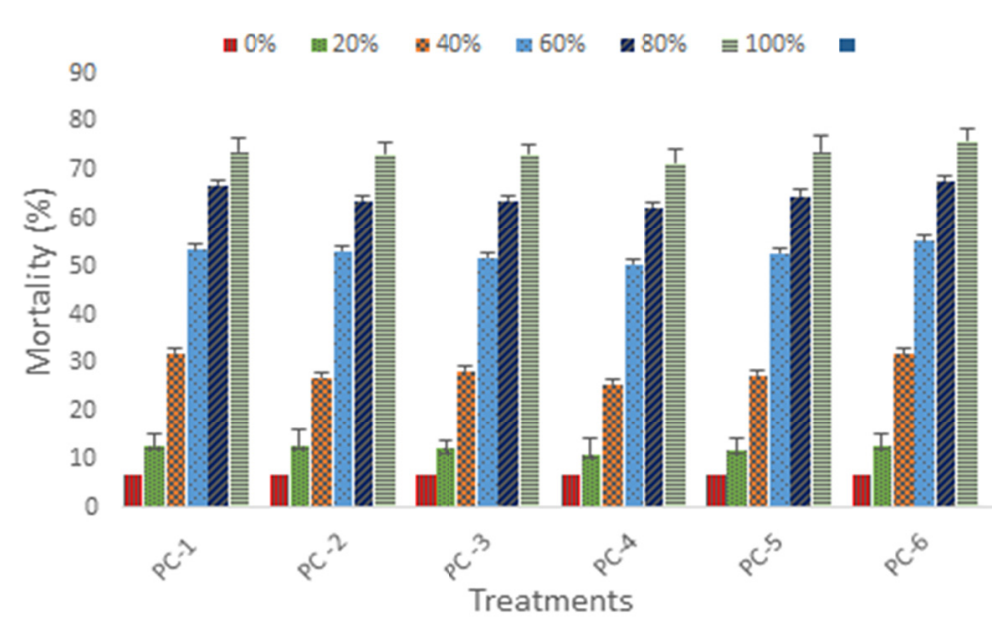

Figure 3. Efficacy of different concentrations of extract of Pochonia chlamydosporia isolates on Mortality (\%) of M. incognita after $72 \mathrm{~h}$ at $25 \pm 1^{\circ} \mathrm{C}$ (Bar represent mean $\pm \mathrm{SD}$ at $P<0.05$ )

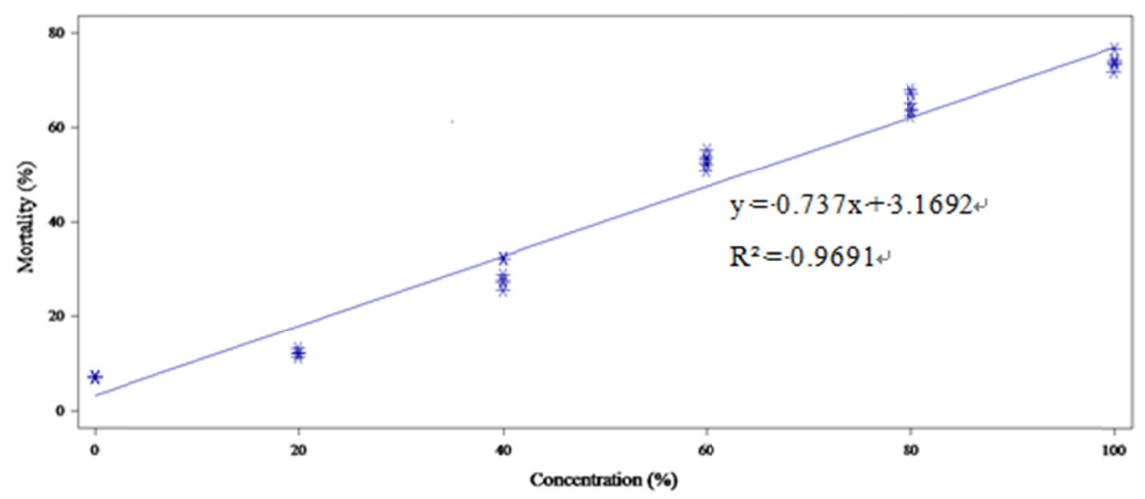

Figure 4. Mortality (\%) of M. incognita against the tested concentrations of the culture filtrate of the isolates of $P$. chlamydosporia $\left(\mathrm{R}^{2}=0.9691\right)$

On the other hands, the eggs and juveniles were infected by isolates after $72 \mathrm{~h}$ of the exposure time. All the isolates showed significant variation $(\mathrm{P} \leq 0.05)$ in parasitism of $M$. incognita eggs and $\mathrm{PC}-1$ caused maximum egg parasitism $(73.7 \%)$ as compared to other isolates (Table 3$)$.

Table 3. Parasitism of different Pochonia chlamydosporia isolates on Meloidogyne incognita eggs and $\mathrm{J}_{2}$ after $72 \mathrm{~h}$ at $25 \pm 1{ }^{\circ} \mathrm{C}$

\begin{tabular}{lll}
\hline Treatments & Egg Parasitism & J2 Parasitism \\
\hline Sterilized distilled water (Control) & $0 \mathrm{D}$ & $0 \mathrm{D}$ \\
\hdashline VC-1 & $73.7 \mathrm{~A}$ & $52.0 \mathrm{AB}$ \\
VC-2 & $68.0 \mathrm{~B}$ & $49.3 \mathrm{BC}$ \\
VC-3 & $65.0 \mathrm{~B}$ & $45.7 \mathrm{BC}$ \\
VC-4 & $56.3 \mathrm{C}$ & $46.0 \mathrm{C}$ \\
VC-5 & $66.7 \mathrm{~B}$ & $49.3 \mathrm{BC}$ \\
VC-6 & $68.3 \mathrm{~B}$ & $54.0 \mathrm{~A}$ \\
\hline Means & $\mathbf{5 6 . 9}$ & $\mathbf{4 2 . 3}$ \\
\hline
\end{tabular}

Note. ${ }^{*}$ LSD value for egg parasitism $=4.400$; LSD value for $\mathrm{J}_{2}=4.070$; Means in the same column followed by different letters are significantly different at 0.05 level of probability.

This was followed by PC-6 and PC-2 with egg parasitism of $68.3 \%$ and $68.0 \%$, respectively. As far as $\mathrm{J} 2$ infection is concerned, the maximum number of larvae (54.0\%) parasitized by PC-6 followed by PC-1 (52.0\%). On the basis of larval mortality and invitro egg inhibition PC-1and PC-6 were selected to study their efficacy 
against $M$. incognita under screen house and field conditions. Significant differences $(\mathrm{P} \leq 0.05)$ were observed among all treatments under screen house conditions (Table 4$)$. Treatment of soil $\left(6 \times 10^{3}\right.$ chlamydospores per gm of soil) with both isolates (PC1 and PC-6) resulted in greater efficacy than the other treatments. Application of chlamydospores applied at rate of $6 \times 10^{3}$ and $2 \times 10^{3}$ chlamydospores per $\mathrm{g}$ of soil were significant $(\mathrm{p}<0.05)$. However, there were no considerable affect using the higher application rate and non-significant differences were observed between treatments of $4 \times 10^{3}$ and $6 \times 10^{3}$ chlamydospores per $g$ of soil. Among the treatments, $\mathrm{T}_{9}$ caused significant higher inhibitory activity of nematode, strong inhibition of gall formation on the roots of tomato plant than those of other formulation.

Table 4. Evaluation of P. chlamydosporia for controlling Meloidogyne incognita in tomato under screen house conditions

\begin{tabular}{|c|c|c|c|c|c|c|c|c|c|c|}
\hline Treatments & $\begin{array}{l}\text { Plant height } \\
\text { (cm) }\end{array}$ & $\begin{array}{l}\text { Fresh shoot } \\
\text { wt (g) }\end{array}$ & $\begin{array}{l}\text { Dry shoot } \\
\text { wt (g) }\end{array}$ & $\begin{array}{l}\text { Fresh root } \\
\text { wt (g) }\end{array}$ & $\begin{array}{l}\text { Dry root } \\
\text { wt (g) }\end{array}$ & $\begin{array}{l}\text { Galls/root } \\
\text { system }\end{array}$ & $\begin{array}{l}\text { Egg masses/g } \\
\text { galled tissue }\end{array}$ & Flowers/plant & Fruits/plant & $\begin{array}{l}\text { Fruit wt/plant } \\
(\mathrm{Kg})\end{array}$ \\
\hline $\mathbf{T}_{\mathbf{o}}$ & $31.00 \mathrm{~A}$ & $35.92 \mathrm{~A}$ & $16.40 \mathrm{~A}$ & $11.58 \mathrm{E}$ & $2.36 \mathrm{D}$ & $0.00 \mathrm{H}$ & $0.00 \mathrm{H}$ & $44.00 \mathrm{~A}$ & $33.60 \mathrm{~A}$ & $1.556 \mathrm{~A}$ \\
\hline$T_{1}$ & $18.60 \mathrm{E}$ & $19.57 \mathrm{~F}$ & $11.46 \mathrm{~F}$ & $16.09 \mathrm{~A}$ & $4.21 \mathrm{~A}$ & $195.6 \mathrm{~A}$ & $84.80 \mathrm{~A}$ & $23.20 \mathrm{E}$ & $15.20 \mathrm{~F}$ & $0.573 \mathrm{D}$ \\
\hline$T_{2}$ & $29.60 \mathrm{~A}$ & $31.12 \mathrm{AB}$ & $14.95 \mathrm{ABC}$ & $12.33 \mathrm{DE}$ & $2.32 \mathrm{D}$ & $0.00 \mathrm{H}$ & $0.00 \mathrm{H}$ & $42.40 \mathrm{AB}$ & $31.40 \mathrm{AB}$ & $1.423 \mathrm{~A}$ \\
\hline $\mathbf{T}_{3}$ & $30.40 \mathrm{~A}$ & $35.69 \mathrm{~A}$ & $15.20 \mathrm{AB}$ & $12.46 \mathrm{DE}$ & $2.33 \mathrm{D}$ & $0.00 \mathrm{H}$ & $0.00 \mathrm{H}$ & $42.80 \mathrm{AB}$ & $32.60 \mathrm{~A}$ & $1.481 \mathrm{~A}$ \\
\hline $\mathbf{T}_{4}$ & $20.60 \mathrm{CDE}$ & $24.63 \mathrm{CDEF}$ & $12.78 \mathrm{BCDEF}$ & $13.22 \mathrm{CD}$ & $3.04 \mathrm{BC}$ & $69.60 \mathrm{E}$ & $67.20 \mathrm{BC}$ & $32.20 \mathrm{BCDE}$ & 19.60 CDEF & $0.722 \mathrm{CD}$ \\
\hline $\mathbf{T}_{5}$ & $22.20 \mathrm{BCD}$ & $26.98 \mathrm{BCDE}$ & $14.00 \mathrm{ABCDE}$ & $12.73 \mathrm{DE}$ & $2.70 \mathrm{CD}$ & $52.60 \mathrm{~F}$ & $65.80 \mathrm{BCD}$ & $35.40 \mathrm{ABCD}$ & $22.40 \mathrm{CDEF}$ & $0.774 \mathrm{BCD}$ \\
\hline$T_{6}$ & $24.80 \mathrm{~B}$ & $29.26 \mathrm{BC}$ & $14.50 \mathrm{ABCD}$ & $12.66 \mathrm{DE}$ & $2.40 \mathrm{D}$ & $38.60 \mathrm{FG}$ & $53.80 \mathrm{DEF}$ & $35.60 \mathrm{ABCD}$ & $24.60 \mathrm{BCD}$ & $1.013 \mathrm{~B}$ \\
\hline $\mathbf{T}_{7}$ & $20.60 \mathrm{CDE}$ & $24.78 \mathrm{CDEF}$ & $12.54 \mathrm{CDEF}$ & $12.76 \mathrm{DE}$ & $3.02 \mathrm{BC}$ & $71.00 \mathrm{E}$ & $51.40 \mathrm{EFG}$ & $34.00 \mathrm{ABCDE}$ & $23.40 \mathrm{CDE}$ & $0.747 \mathrm{BCD}$ \\
\hline $\mathbf{T}_{8}$ & $22.80 \mathrm{BC}$ & $28.52 \mathrm{BCD}$ & $14.30 \mathrm{ABCDE}$ & $12.70 \mathrm{DE}$ & $2.34 \mathrm{D}$ & $45.60 \mathrm{FG}$ & $45.00 \mathrm{FG}$ & $35.80 \mathrm{ABCD}$ & $24.00 \mathrm{BCDE}$ & $0.768 \mathrm{BCD}$ \\
\hline $\mathbf{T}_{9}$ & $25.60 \mathrm{~B}$ & $30.42 \mathrm{AB}$ & $14.82 \mathrm{ABC}$ & $12.54 \mathrm{DE}$ & $2.20 \mathrm{D}$ & $37.60 \mathrm{G}$ & $40.20 \mathrm{G}$ & $38.40 \mathrm{ABC}$ & $27.20 \mathrm{ABC}$ & $1.003 \mathrm{BC}$ \\
\hline $\mathbf{T}_{10}$ & $19.20 \mathrm{DE}$ & $20.00 \mathrm{~F}$ & $11.95 \mathrm{EF}$ & $15.18 \mathrm{AB}$ & $3.52 \mathrm{~B}$ & $171.2 \mathrm{~B}$ & $76.40 \mathrm{AB}$ & $27.00 \mathrm{DE}$ & $16.40 \mathrm{EF}$ & $0.651 \mathrm{D}$ \\
\hline $\mathbf{T}_{11}$ & $19.60 \mathrm{CDE}$ & $21.96 \mathrm{EF}$ & $12.53 \mathrm{CDEF}$ & $14.69 \mathrm{ABC}$ & $3.39 \mathrm{~B}$ & $148.6 \mathrm{C}$ & $67.40 \mathrm{BC}$ & $30.00 \mathrm{CDE}$ & $17.20 \mathrm{DEF}$ & $0.685 \mathrm{D}$ \\
\hline $\mathbf{T}_{12}$ & $20.40 \mathrm{CDE}$ & $24.02 \mathrm{CDEF}$ & 13.03 BCDEF & $13.70 \mathrm{BCD}$ & $2.61 \mathrm{CD}$ & $137.8 \mathrm{C}$ & $59.80 \mathrm{CDE}$ & $35.00 \mathrm{ABCD}$ & $20.00 \mathrm{CDEF}$ & $0.753 \mathrm{BCD}$ \\
\hline $\mathbf{T}_{13}$ & $20.40 \mathrm{CDE}$ & 23.33 DEF & $12.23 \mathrm{DEF}$ & $13.62 \mathrm{CD}$ & $3.48 \mathrm{~B}$ & $151.0 \mathrm{C}$ & $65.40 \mathrm{BCD}$ & $29.40 \mathrm{CDE}$ & $19.60 \mathrm{CDEF}$ & $0.684 \mathrm{D}$ \\
\hline$T_{14}$ & $21.60 \mathrm{CDE}$ & $24.38 \mathrm{CDEF}$ & 12.81 BCDEF & $13.45 \mathrm{CD}$ & $2.61 \mathrm{CD}$ & $120.8 \mathrm{D}$ & $54.20 \mathrm{DEF}$ & $34.60 \mathrm{ABCD}$ & $22.20 \mathrm{CDEF}$ & $0.759 \mathrm{BCD}$ \\
\hline $\mathbf{L S D}_{0.05}$ & 3.596 & 5.564 & 2.542 & 1.518 & 0.574 & 14.255 & 12.379 & 11.153 & 7.684 & 0.289 \\
\hline
\end{tabular}

probability ; To; Control-1 (no nematodes and no fungus, T1; Control-2 (only nematodes and no fungus) T2; only fungus PC-1, T3; only fungus PC-6, T4; 2000 chlamydospores (PC-1) per gram of soil + nematodes, T5; 4000 chlamydospores (PC-1) per gram of soil + nematodes, T6; 6000 chlamydospores (PC-1) per gram of soil + nematodes, T7; 2000 chlamydospores (PC-6) per gram of soil + nematodes, T8; 4000 chlamydospores (PC-6) per gram of soil + nematodes, T9; 6000 chlamydospores (PC-6) per gram of soil + nematodes T10; Substrate alone (no fungus application) T11; Root coating with P. chlamydosporia mycellia (PC-1), T12; Root coating with $P$. chlamydosporia mycellia (PC-6), T13; Root coating with $P$. chlamydosporia chlamydospores (PC-1), T14; Root coating with P. chlamydosporia chlamydospores (PC-6).

Significant increase was noted in plant height $(\mathrm{cm})(37.6 \%)$, fresh shoot wt $(\mathrm{g})(55.4 \%)$ and dry shoot wt $(\mathrm{g})$ (29.3\%) as compared to control under screen house conditions (Table 5). Fresh root weight (g), dry root weight (g), number of galls per plant and number of egg masses per gram of galled tissue of root were decreased by $22.1 \%, 47.7 \%$, and $80.8 \%$ and $53.0 \%$ respectively. Number of flowers and tomato yield in terms of numbers of fruits and total fruit weight were also increased in treated pots. In summer field trials, data indicated that no significant difference was observed among treatments (Table 5). However, considerable effect of the fungal applications was seen in the winter crop (Table 6). $\mathrm{T}_{6}$ was most effective than other formulations. Plant height (44.3\%), fresh shoot wt (g) (51.0\%) and dry shoot wt (g) (70.3\%) were increased as compared to control. Fresh root weight $(\mathrm{g})(38.6 \%)$, dry root weight $(\mathrm{g})(35.5 \%)$, number of galls per plant $(54.9 \%)$ and number of egg masses per gram of galled tissue of root $(66.3 \%)$ were effectively reduced. Significant increase occurred in number of flowers $(51.0 \%)$, fruits $(34.6 \%)$ and total fruit weight $(62.1 \%)$. The Root-knot nematode final population (Pf) of winter crop significantly decreased in all the treatments. Maximum decrease in final population was recorded in $\mathrm{T}_{6}(46.9 \%)$. 
Table 5. Evaluation of P. chlamydosporia for controlling Meloidogyne incognita in summer crop under field conditions

\begin{tabular}{|c|c|c|c|c|c|c|c|c|c|c|c|c|}
\hline Treatments & $\begin{array}{l}\text { Plant height } \\
\text { (cm) }\end{array}$ & $\begin{array}{l}\text { Fresh shoot } \\
\text { wt (g) }\end{array}$ & $\begin{array}{l}\text { Dry shoot } \\
\text { wt (g) }\end{array}$ & $\begin{array}{l}\text { Fresh root } \\
\text { wt (g) }\end{array}$ & $\begin{array}{l}\text { Dry root } \\
\text { wt (g) }\end{array}$ & $\begin{array}{l}\text { Galls/root } \\
\text { system }\end{array}$ & $\begin{array}{l}\text { Egg masses/g } \\
\text { galled tissue }\end{array}$ & $\begin{array}{l}\text { Flowers/ } \\
\text { plant }\end{array}$ & $\begin{array}{l}\text { Fruits/ } \\
\text { plant }\end{array}$ & $\begin{array}{l}\text { Fruit wt/ } \\
\text { plant (Kg) }\end{array}$ & $P i$ & $P f$ \\
\hline $\mathbf{T}_{\mathbf{0}}$ & 68.91 & 79.88 & 17.730 & 26.41 & 8.61 & 146.25 & 85.13 & 80.13 & 38.563 & 1.87 & 165. & 192.125 \\
\hline $\mathbf{T}_{1}$ & 84.00 & 83.995 & 19.90 & 19.69 & 7.76 & 139.00 & 70.63 & 84.75 & 45.813 & 2.20 & 163.19 & 151.750 \\
\hline $\mathbf{T}_{2}$ & 89.69 & 85.19 & 23.168 & 16.50 & 6.55 & 133.00 & 64.50 & 87.13 & 50.500 & 2.55 & 167.81 & 150.125 \\
\hline $\mathbf{T}_{3}$ & 90.91 & 87.49 & 23.927 & 14.58 & 6.27 & 130.00 & 63.19 & 97.99 & 54.750 & 2.71 & 159.33 & 134.750 \\
\hline $\mathbf{T}_{4}$ & 86.93 & 85.90 & 21.400 & 20.79 & 7.55 & 137.00 & 76.19 & 87.38 & 47.375 & 2.40 & 171.00 & 155.125 \\
\hline $\mathbf{T}_{5}$ & 90.31 & 86.895 & 23.413 & 16.29 & 6.67 & 134.00 & 68.50 & 89.44 & 53.688 & 2.69 & 167.44 & 152.063 \\
\hline$T_{6}$ & 96.71 & 87.72 & 24.560 & 14.60 & 6.38 & 129.25 & 62.50 & 104.19 & 59.375 & 3.02 & 152.88 & 138.563 \\
\hline $\mathbf{T}_{7}$ & 72.95 & 79.04 & 18.00 & 25.64 & 8.46 & 144.50 & 84.75 & 80.38 & 39.00 & 1.96 & 158.31 & 180.563 \\
\hline $\mathbf{T}_{8}$ & 76.01 & 79.94 & 17.967 & 23.00 & 8.26 & 135.25 & 74.44 & 82.08 & 39.688 & 1.99 & 160.75 & 152.00 \\
\hline $\mathbf{T}_{9}$ & 82.69 & 87.33 & 21.475 & 20.90 & 6.91 & 128.00 & 73.38 & 86.75 & 47.250 & 2.36 & 172.75 & 156.813 \\
\hline $\mathbf{T}_{10}$ & 87.495 & 86.63 & 18.213 & 22.02 & 8.34 & 138.50 & 71.63 & 81.63 & 42.750 & 2.16 & 165.31 & 148.875 \\
\hline $\mathbf{T}_{11}$ & 88.00 & 87.43 & 21.950 & 17.70 & 6.87 & 133.25 & 69.81 & 86.13 & 47.938 & 2.50 & 163.94 & 151.313 \\
\hline $\operatorname{LSD}_{0.05}$ & 16.454 & 7.033 & 9.555 & 11.142 & 1.856 & 20.932 & 15.287 & 14.439 & 15.30 & 0.819 & 41.120 & 42.574 \\
\hline
\end{tabular}

Note. *Means in the same column followed by different letters are significantly different at 0.05 level of probability. To; Control (no fungus), T1; 2000 Chlamydospores (PC-1) per gram of soil, T2; 4000 Chlamydospores (PC-1) per gram of soil, T3; 6000 Chlamydospores (PC-1) per gram of soil, T4; 2000 Chlamydospores (PC-6) per gram of soil, T5; 4000 Chlamydospores (PC-6) per gram of soil; T6; 6000 Chlamydospores (PC-6) per gram of soil; T7; Substrate alone (no fungus), T8; Root coating with P.chlamydosporia mycellia (PC-1), T9; Root coating with P. chlamydosporia mycellia (PC-6), T10; Root coating with $P$. chlamydosporia chlamydospores (PC-1); T11 Root coating with P.chlamydosporia chlamydospores (PC-6).

Table 6. Evaluation of P.chlamydosporia for controlling Meloidogyne incognita in winter crop under field conditions

\begin{tabular}{|c|c|c|c|c|c|c|c|c|c|c|c|c|}
\hline Treatments & $\begin{array}{l}\text { Plant height } \\
\text { (cm) }\end{array}$ & $\begin{array}{l}\text { Fresh shoot } \\
\text { wt (g) }\end{array}$ & $\begin{array}{l}\text { Dry shoot } \\
\text { wt (g) }\end{array}$ & $\begin{array}{l}\text { Fresh root } \\
\text { wt (g) }\end{array}$ & $\begin{array}{l}\text { Dry root } \\
\text { wt (g) }\end{array}$ & $\begin{array}{l}\text { Galls/root } \\
\text { system }\end{array}$ & $\begin{array}{l}\text { Egg masses/g } \\
\text { galled tissue }\end{array}$ & $\begin{array}{l}\text { Flowers/ } \\
\text { plant }\end{array}$ & $\begin{array}{l}\text { Fruits/ } \\
\text { plant }\end{array}$ & $\begin{array}{l}\text { Fruit wt/ } \\
\text { plant (Kg) }\end{array}$ & $P i$ & $P f$ \\
\hline $\mathbf{T}_{\mathrm{o}}$ & $60.50 \mathrm{D}$ & $59.99 \mathrm{~F}$ & $12.95 \mathrm{E}$ & $23.65 \mathrm{~A}$ & $9.530 \mathrm{~A}$ & $128.5 \mathrm{~A}$ & $87.63 \mathrm{~A}$ & $58.94 \mathrm{D}$ & $37.75 \mathrm{E}$ & $1.672 \mathrm{D}$ & $192.1 \mathrm{~A}$ & $220.1 \mathrm{~A}$ \\
\hline $\mathbf{T}_{1}$ & $73.36 \mathrm{ABCD}$ & $70.64 \mathrm{DEF}$ & $16.82 \mathrm{ABCDE}$ & $22.11 \mathrm{AB}$ & $7.925 \mathrm{ABC}$ & $82.06 \mathrm{E}$ & $51.88 \mathrm{BC}$ & $79.88 \mathrm{ABC}$ & $42.81 \mathrm{BCDE}$ & $2.150 \mathrm{BCD}$ & $151.8 \mathrm{ABC}$ & $132.8 \mathrm{C}$ \\
\hline $\mathbf{T}_{2}$ & $78.90 \mathrm{ABC}$ & 83.23 $\mathrm{ABCD}$ & $19.91 \mathrm{ABCD}$ & $19.06 \mathrm{ABC}$ & $6.935 \mathrm{BC}$ & $78.00 \mathrm{EF}$ & $40.00 \mathrm{CDEF}$ & $82.44 \mathrm{ABC}$ & $45.69 \mathrm{ABC}$ & $2.287 \mathrm{ABC}$ & $150.1 \mathrm{ABC}$ & $127.7 \mathrm{C}$ \\
\hline $\mathbf{T}_{3}$ & $84.17 \mathrm{AB}$ & $88.03 \mathrm{AB}$ & $20.92 \mathrm{AB}$ & $17.39 \mathrm{BC}$ & $6.755 \mathrm{BC}$ & $59.25 \mathrm{G}$ & $30.38 \mathrm{EF}$ & $87.19 \mathrm{~A}$ & $49.38 \mathrm{AB}$ & $2.495 \mathrm{AB}$ & $134.8 \mathrm{C}$ & $117.4 \mathrm{C}$ \\
\hline $\mathbf{T}_{4}$ & $78.32 \mathrm{ABC}$ & $72.13 \mathrm{CDEF}$ & $16.86 \mathrm{ABCDE}$ & $21.80 \mathrm{AB}$ & $6.932 \mathrm{BC}$ & $81.69 \mathrm{E}$ & $54.56 \mathrm{~B}$ & $83.75 \mathrm{ABC}$ & $43.13 \mathrm{BCDE}$ & $2.283 \mathrm{ABC}$ & $155.1 \mathrm{ABC}$ & $157.8 \mathrm{BC}$ \\
\hline $\mathbf{T}_{5}$ & $82.97 \mathrm{AB}$ & $86.80 \mathrm{ABC}$ & $20.75 \mathrm{ABC}$ & 17.72BC & $6.912 \mathrm{BC}$ & $63.38 \mathrm{EG}$ & $39.31 \mathrm{DEF}$ & $85.06 \mathrm{AB}$ & $48.13 \mathrm{ABC}$ & $2.365 \mathrm{AB}$ & $152.1 \mathrm{ABC}$ & $117.2 \mathrm{C}$ \\
\hline$T_{6}$ & $87.31 \mathrm{~A}$ & $90.56 \mathrm{~A}$ & $22.05 \mathrm{~A}$ & $14.52 \mathrm{C}$ & $6.145 \mathrm{C}$ & $58.00 \mathrm{G}$ & $29.50 \mathrm{~F}$ & $89.00 \mathrm{~A}$ & $50.81 \mathrm{~A}$ & $2.710 \mathrm{~A}$ & $138.6 \mathrm{BC}$ & $116.9 \mathrm{C}$ \\
\hline $\mathbf{T}_{7}$ & $62.00 \mathrm{D}$ & $63.29 \mathrm{EF}$ & $15.46 \mathrm{DE}$ & $22.46 \mathrm{AB}$ & $9.145 \mathrm{~A}$ & $122.8 \mathrm{AB}$ & $84.25 \mathrm{~A}$ & $66.88 \mathrm{CD}$ & $38.13 \mathrm{DE}$ & $1.748 \mathrm{CD}$ & $180.6 \mathrm{AB}$ & $199.8 \mathrm{AB}$ \\
\hline $\mathbf{T}_{8}$ & $64.37 \mathrm{CD}$ & $70.50 \mathrm{DEF}$ & $15.54 \mathrm{CDE}$ & $21.74 \mathrm{AB}$ & $8.145 \mathrm{AB}$ & $108.1 \mathrm{BC}$ & $55.44 \mathrm{~B}$ & $69.94 \mathrm{BCD}$ & $41.63 \mathrm{CDE}$ & $1.765 \mathrm{CD}$ & $152.0 \mathrm{ABC}$ & $124.0 \mathrm{C}$ \\
\hline$T_{9}$ & $71.10 \mathrm{BCD}$ & $71.71 \mathrm{DEF}$ & 16.75 $\mathrm{BCDE}$ & $21.48 \mathrm{AB}$ & $7.555 \mathrm{ABC}$ & $91.69 \mathrm{DE}$ & $41.75 \mathrm{CDE}$ & $76.94 \mathrm{ABC}$ & $44.38 \mathrm{ABCDE}$ & $2.082 \mathrm{BCD}$ & $156.8 \mathrm{ABC}$ & $127.1 \mathrm{C}$ \\
\hline$T_{10}$ & $69.63 \mathrm{BCD}$ & 75.67 BCDE & $18.13 \mathrm{ABCDE}$ & $21.69 \mathrm{AB}$ & $8.622 \mathrm{AB}$ & $100.4 \mathrm{CD}$ & $49.75 \mathrm{BCD}$ & $76.75 \mathrm{ABC}$ & $42.38 \mathrm{BCDE}$ & $1.960 \mathrm{BCD}$ & $148.9 \mathrm{BC}$ & $142.6 \mathrm{C}$ \\
\hline $\mathbf{T}_{11}$ & $72.35 \mathrm{ABCD}$ & $77.50 \mathrm{ABCDE}$ & 18.87 ABCD & $21.22 \mathrm{AB}$ & $7.733 \mathrm{ABC}$ & $79.06 \mathrm{E}$ & $41.56 \mathrm{CDE}$ & $80.63 \mathrm{ABC}$ & $45.38 \mathrm{ABCD}$ & $2.225 \mathrm{ABCD}$ & $151.3 \mathrm{ABC}$ & $130.1 \mathrm{C}$ \\
\hline LSD $_{0.05}$ & 16.018 & 14.884 & 5.281 & 5.082 & 1.980 & 15.624 & 11.896 & 17.107 & 7.434 & 0.553 & 42.574 & 42.973 \\
\hline
\end{tabular}

Note. *Means in the same column followed by different letters are significantly different at 0.05 level of probability. To; Control (no fungus), T1; 2000 Chlamydospores (PC-1) per gram of soil, T2; 4000 Chlamydospores (PC-1) per gram of soil, T3; 6000 Chlamydospores (PC-1) per gram of soil, T4; 2000 Chlamydospores (PC-6) per gram of soil, T5; 4000 Chlamydospores (PC-6) per gram of soil; T6; 6000 Chlamydospores (PC-6) per gram of soil; T7; Substrate alone (no fungus), T8; Root coating with $P$. chlamydosporia mycellia (PC-1), T9; Root coating with P.chlamydosporia mycellia (PC-6), T10; Root coating with P.chlamydosporia chlamydospores (PC-1); T11 Root coating with P.chlamydosporia chlamydospores (PC-6).

\section{Discussion}

P. chlamydosporia has been reported as biological control agent against cyst and root-knot nematodes (Saifullah, 
1996). The isolates have variable effect on M. incognita (Bourne, Kerry, \& De Leij, 1994; Kerry Jaffee, 1997). Current study showed that culture filtrate of $P$. chlamydosporia isolates strongly affected $\mathrm{J} 2$ mortality and egg hatching of $M$. incognita. We also noted that increasing the concentration of culture filtrate increased egg hatch inhibition and $\mathrm{J}_{2}$ mortality, and thus confirming the previous finding (Mukhtar \& Pervaz, 2003). Effect of the CF from several fungi on egg hatch and $\mathrm{J}_{2}$ mortality of nematodes have also been previously reported (Randhawa, Singh, Sandhu, \& Bhatia, 2001; Zaki, 1999). Isolates PC-6 and PC-1 strongly inhibited egg hatch and killed $\mathbf{J}_{2}$. Both isolates (PC-1 and PC6) showed considerable variations in egg parasitism. PC-1 parasitized maximum number of eggs (73.7\%) followed by PC-6 (68.3\%). Ebadi et al. (2009) also recorded more than $85 \%$ of $M$. javanica eggs parasitized by $P$. chlamydosporia.

Non-significant difference was noted between PC-1 and PC-6 in the case of juvenile mortality. On the other hand PC-1 seems to be more effective than PC-6 in killing nematode eggs. This may be due the high production of egg shell degrading enzymes by PC-1. Nematicidal effect was not seen in potato dextrose broth (culture media) and thus did not differ significantly as compared to water (control). This supports the finding of Singha and Mathurb (2010) and contradicts the findings of Nitao et al. (1999).

The selected isolates (PC-1 and PC-6) of P. chlamydosporia were tested under screen house and field conditions using different application rates and methods. Inoculum level of the bio agent has a significant effect on its host (Zareen \& Zaki, 2001). Both PC-1 and PC-6 were found to be more active when applied at rate of $6 \times 10^{3}$ chlamydospores/gm of soil. Significant difference was noted between treatments where chlamydospores applied at rate of $2 \times 10^{3}$ and $6 \times 10^{3}$ per gram of soil. Both isolates of $P$. chlamydosporia suppressed nematodes and improved plant growth in tomatoes, however, no statistical difference was recorded between the isolates. Under field conditions, isolates did not exhibit any significant difference for their effectiveness in summer crop. On the other hand, significant variation was noted among treatments in winter crop. Galling indices was highly reduced in winter crop irrespective to the application rate and method of application as compared to summer crop. This might be due to low cfu/gm of both isolates in soil during summer and thus confirming the previous finding (Vieira dos Santos, Esteves, Kerry, \& Abrantes, 2014).

\section{Conclusion}

The isolates of P.chamydosporia produced compounds which have potential as novel nematicides. In the present study, the two isloates (PC-1 and PC-6) were effective against egg hatching, egg parasitism mortality of second stage juveniles of $M$. incognita under invitro condition. In screen house and field trial both isolates showed good biocontrol potential against $M$. incognita. Root coating with chlamydospores application method was found to be more effective than mycelial root coating in the current study. No lesions were noticed on P. chlamydosporia treated roots of tomato plant which reveals that the tested fungus is safe. Further research work is needed for the molecular characterization of these isolates, and isolattion and structure elucidation of nematicidal compounds produced by two isolates.

\section{Acknowledgements}

The authors are highly grateful to Vice Chancellor Khyber Pakhtunkhwa Agricultural University Peshawar, Pakistan for providing all facilities for this project.

\section{References}

Agrios, G. N. (2004). Plant Pathology (5th ed., p. 635). Academic Press, San Diego, California, USA.

Ayatollahy, E., Fatemy, S., \& Etebarian, H. R. (2008). Potential for Biological Control of Heterodera schachtii by Pochonia chlamydosporia var. Chlamydosporia on Sugar Beet. Biocontrol Science and Technology, 18, 157-167. https://doi.org/10.1080/09583150701824079

Barker, K., Carter, R., \& Sasser, J. N. (1985). Identification of Meloidogyne spp. on the basis of differential host test and perineal pattern morphology: An Advanced Treatise on Meloidogyne. Methodology, 2, 69-75.

Barnett, H. L., \& Hunter, B. B. (1998). Illustrated Genera of Imperfect Fungi (4th ed., p. 218). APS Press, St. Paul.

Bourne, J. M., \& Kerry, B. R. (2000). Observations on the survival and competitive ability of the nematophagous fungus Verticillium chlamydosporium in soil. International Journal of Nematology, 10, 9-18.

Bourne, J. M., Kerry, B. R., \& De Leij, F. A. A. M. (1994). Method for the study of $P$. chlamydosporia in the rhizosphere. Journal of Nematology, 26, 587-591. 
Briar, S. S., Wichman, D., \& Reddy, G. V. (2016). Plant-parasitic nematode problems in organic agriculture. In D. Nandawani (Ed.), Organic Farming for Sustainable Agriculture (pp. 107-122). Springer International Publishing. https://doi.org/10.1007/978-3-319-26803-3_5

Crump, D. H., \& Kerry, B. R. (1981). A quantitative method for extracting resting spores of two nematode parasitic fungi, Nematophthora gynophila and P. chlamydosporia from soil. Nematologica, 26, 330-339.

De Leij F. A. A. M., \& Kerry, B. R. (1991). The nematophagous fungus P. chlamydosporia as a potential biological control agent for Meloidogyne arenaria. Revue de Nematologie, 14, 157-164.

Duponnois, R., Chotte, J. L. \& Sall, S. (2001). The effect of organic amendments on the interactions between a nematophagous fungus Arthrobotrys oligospora and the root-knot nematode, Meloidogyne mayaguensis parasitizing tomato plants. Biological Fertilization Soils, 34, 1-6. https://doi.org/10.1007/s003740100344

Ebadi, M., Fatemy, S., \& Riahi, H. (2009). Evaluation of Pochonia chlamydosporia var. Chlamydosporia as a control agent of Meloidogyne javanica on pistachio. Biocontrol Science and Technology, 19, 689-700. https://doi.org/10.1080/09583150903051844

Freire, F. C. O., \& Bridge, J. (1985). Parasitism of eggs, female and juveniles of Meloidogyne incognita by Paecilomyces lilacinus and P. chlamydosporia. Fitopatologia Brasileira, 10, 577-596.

Garima, G., Singh, A., \& Trivedi, P. C. (2005). Bacteria: A Potential bio agent against Root-knot nematode, Meloidogyne incognita (p. 14). National Symposium on Recent Advances and Research Priorities in Indian Nematology, 9-10th December 2005, IARI, New Delhi.

Hirooka, T., \& Ishii, H. (2013). Chemical control of plant diseases. Journal of General Plant Pathology, 79(6). https://doi.org/10.1007/s10327-013-0470-6

Hussey, R. S., \& Barker, K. R. (1973). A comparison of methods of collecting inocula of Meloidogyne spp., including a new technique. Plant Disease Reporter, 57, 1025-1028.

Kerry, B. R. \& Bourne, J. M. (2002). A manual for research on P. chlamydosporia, a potential biological control agent for root-knot nematodes (p. 84). Gent, Belgium, IOBC-OILB.

Kerry, B. R. (1986). An assessment of the role of parasites and predators in the regulation of the cyst nematode populations. In F. Lamberti \& C. E. Taylor (Eds.), Advanced Institutes Series (Ser. A, Vol. 121, pp. 433-450). NATO.

Kerry, B. R. (2000). Rhizosphere interactions and the exploitation of microbial agents for the biological control of nematodes. Phytopathology, 38, 423-441. https://doi.org/10.1146/annurev.phyto.38.1.423

Kerry, B. R., \& Crump D. H. (1977). Observations on fungal parasites of females and eggs of the cereal cyst-nematode, neterodera avenae, and other cyst nematodes. Nematologica, 23, 193-201. https://doi.org/ $10.1163 / 187529277 \mathrm{X} 00543$

Kerry, B. R., \&Jaffee, B. A. (1997). Fungi as biological control agents for plant-parasitic nematodes. In D. T. Wicklow, \& B. E. Soderstrom (Eds.), The Mycota: A Comprehensive Treatise on Fungi as Experimental Systems for Basic Applied Research Environmental and Microbial Relationships (Vol. 4, pp. 203-218). Berlin, Germany: Springer.

Kerry, B. R., Kirkwood, I. A., De Leij, F. A. A. M., Barba, J., Leajdens, M. B., \& Brookes, P. C. (1993). Growth and survival of Verticillium chlamydosporium Goddard, a parasite of nematodes, in soil. Biocontrol Science and Technology, 3, 355-365. https://doi.org/10.1080/09583159309355290

Kopcke, B., Wolf, D., Anke, H., \& Sterner, O. (2001). New natural products with nematicidal activity from fungi. British Mycological Society International Symposium, Bioactive Fungal Metabolites-Impact and Exploitation, UW Swansea, UK.

Lopez-Llorca, L. V., Macia-Vicente, J. G., \& Jansson, H. B. (2008). Mode of Action and Interactions of Nematophagous Fungi. In A. Ciancio, \& K. G. Mukerji (Eds.), Integrated Management and Biocontrol of Vegetable and Grain Crops Nematodes (Vol 2.). Integrated Management of Plant Pests and Diseases Springer, Dordrecht.

Manzanalla-Lopez, R. H., Esteves, I., Finetta-Sialer, M. M., Hirsch, P. R., Ward, E., Devonshire, J., \& Hydalgo-Diaz, L. (2013). Pochonia chlamydosporia: Advances and challenges to improve its performance as a biological control agent of sedentary endo-parasitic nematodes. Journal of Nematology, 45, 1-7. 
Manzanilla-López, R. H., Esteves, I., Finetti-Sialer, M. M., Hirsch, P. R., Ward, E., Devonshire, J., \& Hidalgo-Díaz, L. (2013). Pochonia chlamydosporia: Advances and Challenges to Improve Its Performance as a Biological Control Agent of Sedentary Endo-parasitic Nematodes. Journal of Nematology, 45, 1-7.

Martin, F. N. (2003). Development of alternative strategies for management of soilborne pathogens 950 currently controlled with methyl bromide. Annual Review of Phytopathology, 41, 325-350. https://doi.org/10.1146/ annurev.phyto.41.052002.095514

Mukhtar, T., \& Pervaz, I. (2003). In vitro evaluation of ovicidal and larvicidal effects of culture filtrate of $P$. chlamydosporia against Meloidogyne javanica. International Journal of Agriculture and Biology, 5, 576-579.

Musarrat, A., Firoza, R., \& Shahina, F. (2006). Study of Root-knot Nematodes (Meloidogyne) in NWFP and Sindh, Pakistan. Pakistan Journal of Nematology, 24, 1-7.

Nitao, J. K., Meyer, S. L., \& Chitwood, D. J. (1999). In-vitro Assays of Meloidogyne incognita and Heterodera glycines for Detection of Nematode-antagonistic Fungal Compounds. Journal of Nematology, 31, 172-83.

Ornat, C., \& Sorribas, F. J. (2008). Integrated management of root-knot nematodes in mediterranean horticultural crops. In A. Cianco, \& K. G. Mukerji (Eds.), Integrated Management and Biocontrol of Vegetable and Grain Crops Nematodes (Vol 2, pp. 295-319). Springer, Dordrecht (NLD), Integrated Management of Plant Pests and Diseases.

Palomares-Rius, J. E., Escobar, C., Cabrera, J., Vovlas, A., \& Castillo, P. (2017). Anatomical Alterations in Plant Tissues Induced by Plant-Parasitic Nematodes. Frontiers in Plant Science, 8, 1987. https://doi.org/10.3389/ fpls.2017.01987

Ploeg, A. T. (2002). Effect of selected Marigold varieties on Root-knot nematodes and tomato and melon yields. Plant Disease, 86, 505-508. https://doi.org/10.1094/PDIS.2002.86.5.505

Randhawa, N., Singh, P., Sandhu, K. S., \& Bhatia, A. (2001). Effect of culture filtrates of soil fungi on hatching of Meloidogyne incognita. Plant Disease Research, 16, 280-282.

Saifullah. (1996). Nematicidal and Nematostatic effect of cell-free culture filtrate of $P$. chlamydosporia Goddard in vitro. Afro-Asian Journal of Nematology, 6, 32-35.

Sikora, R. A., \& Fernandez, E. (2005). Nematodes parasites of vegetables. In M. Liuc, R. A. Sikora, \& J. Bridge (Eds.), Plant Parasitic Nematodes in Subtropical and Tropical Agriculture (pp. 319-392). CAB International, Wallingford (GBR).

Singha S., \& Mathurb, N. (2010). In vitro studies of antagonistic fungi against the root-knot nematode, Meloidogyne incognita. Biocontrol Science and Technology, 20, 27-5282.

Steel, R. G. D., \&Torrie, J. H. (1980). Principles and procedures of statistics (p. 480). McGraw Hill Book, Co., Inc. New York.

Sun, M. H., Gao, L., Shi, Y. X., Li, B. J., \& Liu, X. Z. (2006). Fungi and actinomycetes associated with Meloidogyne spp. eggs and females in China and their bio control potential. Journal of Invertebrate Pathology, 93, 22-28. https://doi.org/10.1016/j.jip.2006.03.006

Tikhonov, E. V., Lopez-Llorca, L. V., Salinas, J. S., \& Jansson, H. B. R. (2002). Purification and characterization of chitinases from the nematophagous fungi $P$. chlamydosporia and $V$. suchlasporium. Fungal Genetics and Biology, 35, 67-78. https://doi.org/10.1006/fgbi.2001.1312

Verdejo-Lucas, S., Sorribas, F. J., Ornat, C., \& Galeano, M. (2003). Evaluating Pochonia chlamydosporia in a double-cropping system of lettuce and tomato in plastic houses infested with Meloidogyne javanica. Plant Pathology, 52, 521-528. https://doi.org/10.1046/j.1365-3059.2003.00873.x

Vieira dos Santos, M. C., Esteves, I., Kerry, B., \& Abrantes, I. (2014). Interactions between Pochonia chlamydosporia and Meloidogyne chitwoodi in a crop rotation scheme. Nematropica, 44, 37-46.

Walker, J. C. (1983). Diseases of vegetable crops (pp. 431-515). McGraw Hill Book, Co. Inc., New York.

Zaki, M. J. (1999). Effect of fungal culture filtrates on mortality and hatching of Meloidogyne javanica. Pakistan Journal of Biological Sciences, 2, 161-3. https://doi.org/10.3923/pjbs.1999.161.163

Zareen, A. \& Zaki, M. J. (2001). Effect of different inoculum levels of P. chlamydosporia (Goddard) on Meloidogyne javanica Root-knot nematode. Pakistan Journal of Botany, 33, 674-6. 


\section{Copyrights}

Copyright for this article is retained by the author(s), with first publication rights granted to the journal.

This is an open-access article distributed under the terms and conditions of the Creative Commons Attribution license (http://creativecommons.org/licenses/by/4.0/). 